\title{
Study on Cultural Input and Output Strategies in College English Teaching
}

\author{
Yani Zong \\ Xi’an International University, Xi'an, Shaanxi, 710077
}

Keywords: College English; Cultural Transport; Strategy Research

\begin{abstract}
Globalization has brought the collision of cultures between nations, and it has become more and more important for English learning. In this context, how to improve the level of English students, how to grasp the integration of cultural elements in English teaching, how to ensure that English teaching in the case of local culture, and how to foreign excellent culture as a current focus of the work of university teachers in English teaching, the need to carefully grasp the Chinese and foreign cultures affect the degree of mutual transmission, so that students better to learn and improve. According to the relevant information, combined with their own experience, the author will discuss the input and output of culture, and study how to input and output the operation strategy, in order to improve the students' English level and comprehensive quality.
\end{abstract}

\section{Introduction}

English teaching for college students is mainly to enable students to get better development, contact more diverse culture, so that students of professional quality and comprehensive ability to be all-round upgrade, so that students can continue to self-improvement, access to competitive advantage. English teaching is not a simple language teaching, try vocabulary grammar and so on to instill students, or an important way for students to perceive cultural diversity, so that students can more in-depth understanding of other countries, to receive other excellent cultural baptism, feel the charm from the cultural diversity [1]. The global contact is getting closer and closer, the cultural collision is more and more intense, different races, different languages, different colors and different cultures bring different learning perspective, for English learning into the fresh blood, but also let Language and cultural depth of integration. College English teaching needs to combine language and culture, and the introduction of foreign culture, but also the need to integrate oriental culture into English teaching, so as to cultivate a multi-cultural impact of the open thinking of a comprehensive talent.

\section{The College English Teaching in Cultural Input}

Language is the carrier of culture, the accumulation of culture, the image of culture, but also part of the culture. English culture at the same time, the English-speaking countries also followed the process of globalization into the process. This provides a new task for college English teaching, namely: in the implementation of teaching activities in the process of college English learners to enter the target language culture. "Culture input" teaching model is a way to guide students to take the initiative to construct language and cultural knowledge, to promote the comprehensive use of English ability to improve the relatively stable operational framework [2]. The model advocates teachers in a certain teaching environment, according to the syllabus, teaching materials and student practice, the correct way to actively guide students to stimulate their thinking and imagination, to promote students to take the initiative to construct the internal psychological representation, so as to develop students Sensitivity to cultural differences, tolerance and the flexibility to deal with cultural differences, and to improve students' ability to use English comprehensively [3]. In college English learning, the lack of knowledge of target language culture will cause many errors in language use, such as Chinese English phenomenon. 
At present, there are many scholars in the field of language teaching and it has a more in-depth understanding of cultural input teaching, put forward some principles conducive to education. For example, scholars Ding Dingfang, proposed in the language output need to focus on practical principles, in addition, also need to learn according to the students to carry out specific analysis, different stages of the application of different methods, follow the stage principle. English teaching is to follow the general law, in the cultural input to moderate, can not be based on the reality of the blind introduction, according to the students' learning level, learning progress and learning conditions to be appropriate introduction, and the need for gradual introduction, step by step Stage introduction, only this infiltration of English teaching can make the teaching effect to the greatest degree of play. In addition, in the teaching, but also need to follow the practical principles, teaching is to make the knowledge to be applied, if the content of the professor out of reality, no use will lose the meaning of teaching, so the cultural input to follow practical Principle, apply their knowledge. Finally, we must follow the appropriate principle, in the cultural input to select the content to be selected, will be repeated, negative, unhealthy information culture removed, so that cultural input more accurate, more pure really do its essence.

For an independent country, its most important element is culture, culture is a national history of precipitation, but also the basis for future development, is a national soft power embodiment, but also the national strength of the side. Culture is a country of language, humanities, folklore, history, thought, is abstract and concrete. Therefore, in English teaching, of course, is standing on the language and culture point of view, in order to carry out the correct three-dimensional cultural input, we must recognize the cultural connotation. Cultural input can be derived from language vocabulary, cultural history, and communication. Vocabulary language is a country's most important logo, in a country's language, the vocabulary can be said to be the soul of language, is the direct expression of culture, to deepen the vocabulary of learning, cultural input is more direct and rapid students the key to language learning is the best way to improve language sensitivity. Idioms as a national culture embodies, is the most national characteristics, but also the richest national flavor, is the essence of cultural development. The introduction of idioms, not only to enable students to experience the beauty of language, appreciate the charm of culture, but also from the idioms in a rapid understanding of a country's culture, improve the efficiency of learning. Teachers are in the teaching, the need to continue to extend the extension of the word, such as idioms, in foreign culture, how the spirit of expression, how to express the story, condensation of what kind of wisdom, and to correctly guide students for cultural differences view. For the communication side, it is the traditional social etiquette and a country's folk customs to teach. In English learning, Western countries have what kind of social etiquette, what kind of cultural characteristics and folk customs, need to grasp the learners in order to avoid the cultural differences and some embarrassing situation. English teaching will be the introduction of these cultural aspects of communication, is to allow students to learn more in English, more in-depth. Finally, in the cultural history also have to learn, for teaching materials involved in the cultural and historical information to be targeted to explain, for cultural history allows students to learn English more in-depth, more three-dimensional. Historical background is a country's most profound cultural response, only the cultural background of the master, in order to truly from the English language learning.

\section{The mother tongue culture output}

English globalization at the same time, because the nation has its unique history, culture, politics, economy, environment and national psychology background, is bound to produce localization phenomenon [4]. It is the English language and culture and other long-term contact with the product of variation. The localization of English in China includes both the Chinese characteristics of the language, that is, the formation of Chinese English variants, including the transfer of Chinese culture, that is, English as the carrier of Chinese culture and the media. The development of English localization has put forward new requirements for English learning, namely: to strengthen the study of mother tongue culture, in the international exchange to increase the output of the mother tongue culture [5]. 
As a country with excellent cultural history, China's mother tongue culture has a very important position. In the current English teaching, the mother tongue is to enable students to learn English and more understanding of the content of the course is the most important factor in English learning. How to combine the English culture with the oriental culture let the mother tongue culture play a positive role in the study of English learning, and play a positive guiding role in English learning. Whether it is standing in the student's point of view, or standing in the development of the point of view, must be cultural output, one-way cultural input will be students Westernization, breaking the cultural balance, ignoring the cultural output will bring college students distortions of values. Only in the English teaching to achieve reciprocal two-way output and input, in order to achieve common development and common progress of the win-win situation [6]. In English learning, teachers should correctly guide students to language learning, for the traditional culture and Western culture to establish a correct understanding of the local culture into the English teaching for cultural heritage to carry forward the correct understanding of the students' culture, for students' English learning has a very important significance.

In the cultural output, we must start from the teacher's own, teachers should not only realize their own responsibility, but also because of ignoring the cultural output brought about such as "Chinese culture aphasia" and other special phenomena. After correctly understanding the current teaching environment, English teachers need to adjust the teaching content, for the integration of traditional culture, for the expansion of relevant knowledge points and should be strengthened. In addition, the teaching methods have to make adjustments, to introduce the traditional elements, advancing with the times, to develop appropriate teaching methods. It can be appropriate for cultural contrast teaching model, so that students in English learning can also feel the charm of oriental culture. In the collision of two cultures, it has more in-depth understanding of the traditional culture and learning English courses. In the cultural output, the teacher's responsibility is significant. English teachers' own cultural literacy directly determines the quality of teaching and the level of teaching, in the teaching, the quality of students and leisure level is directly linked with the teacher. Therefore, in the cultural output, we must continue to improve the quality of teachers themselves, so that teachers have a deep understanding of traditional culture, and continue to improve their literary literacy, in order to correctly guide students, so that students appreciate the local the charm of culture, the completion of cultural output.

\section{Conclusion}

Different countries, different cultures, different languages, in the globalization of mutual integration, mutual influence, in college English teaching, to correctly understand the combination of this culture and transmission, both in the introduction of excellent culture, or in the traditional culture of the output are required to teachers between the correct grasp of the two, in English teaching, teachers not only in the teaching content, teaching model to make changes, but also from their own, to strengthen their own cultural construction and concept of cognition, the students to guide the right. Due to the limitations of cognition, the author's view on the related issues is still relatively simple, but also need more experts and scholars to criticize the correction.

\section{References}

[1] Zhang Zhongyan. College English teaching in our mother tongue culture input and output correlation between the study [D]. Yangtze River University, 2012

[2] Liu Jian. Study on Chinese-English Cultural Input and Output in College English Translation Teaching[J]. Journal of Qiqihar Teachers College, 2015,05: 149-150.

[3] Feng Ya-juan. Effects of English Movies in Advanced English Audio-Visual Teaching in College English - Using English Language and Cultural Input Advantages and Spatial Intelligent Storage Activation Schema[J]. Journal of Beijing Second Foreign Language Institute, 2010, 02: 58- 61

[4] Lu Caiyao. College English listening and speaking teaching based on Krashen input hypothesis 
and Swain output hypothesis [J]. Overseas English, 2011,06: 62-63 + 67 .

[5] Huang Lan. From the input and output theory to see the original film in college English oral teaching application[J]. Huaihai Institute of Technology (Social Science Edition), 2011, 18: 69-71

[6] Wen Jinhai, Cao Wu. Vocabulary input link in college English classroom teaching under the mode of strategy - Taking PPT courseware of $21 \sim$ (st) College English (Book 2 Unit 4 Text A) as an example [J]. Crazy English (Teacher Edition), 2008, 01: 27-31 